\title{
Prevalence of thyroid dysfunction and its effects on fetomaternal outcome in pregnant women of Eastern Uttar Pradesh, India
}

\author{
Ankita Kumari ${ }^{1 *}$, Reena Srivastav ${ }^{1}$, Shaila Mitra ${ }^{2}$ \\ ${ }^{1}$ Department of Obstetrics and Gynecology, ${ }^{2}$ Department of Pathology, BRD Medical College, Gorakhpur, Uttar
} Pradesh, India

Received: 18 September 2018

Accepted: 24 September 2018

*Correspondence:

Dr. Ankita Kumari,

E-mail: drankita09@gmail.com

Copyright: $\odot$ the author(s), publisher and licensee Medip Academy. This is an open-access article distributed under the terms of the Creative Commons Attribution Non-Commercial License, which permits unrestricted non-commercial use, distribution, and reproduction in any medium, provided the original work is properly cited.

\section{ABSTRACT}

Background: The aim of the study is to determine the prevalence of thyroid dysfunction in pregnancy and its impact on obstetrical outcome in Eastern Uttar Pradesh.

Methods: This was a prospective observational study undertaken at antenatal clinics and indoor of BRD Medical College, Gorakhpur. Total 720 antenatal women, $\leq 20$ weeks of gestation were recruited for the study. In all patients' routine obstetrical investigations and thyroid function tests were done. All patients were followed up to delivery. Maternal and perinatal outcome were ascertained.

Results: Prevalence of thyroid dysfunction among pregnant was found to be $21.1 \%$ and subclinical hypothyroidism (15.9\%) was the commonest thyroid disorder. Most common complication observed in subclinical and overt hypothyroidism was preeclampsia $(9.56 \%$ versus $20 \%$ ) followed by preterm labour ( $7.82 \%$ versus $10 \%)$. Major fetal complications in hypothyroid mothers included intrauterine growth restriction, low birth weight and stillbirth.

Conclusions: Prevalence of hypothyroidism was found to be high in our study and was associated with adverse pregnancy outcomes; hence, thyroid screening should be included in routine antenatal investigations.

Keywords: Intrauterine growth restriction, Low birth weight, Obstetrical outcome, Preeclampsia, Preterm labour, Thyroid dysfunction

\section{INTRODUCTION}

Thyroid dysfunction constitutes as a major problem in women of childbearing age, which has an important implication in pregnancy and the puerperium for both mother and the baby. The most frequent thyroid disorder in pregnancy is maternal hypothyroidism. It can lead to premature birth, preeclampsia, increased fetal mortality and low birth weight. ${ }^{1-4}$ Maternal hypothyroidism in the first trimester of pregnancy may be harmful to fetal brain development and lead to mental retardation., ${ }^{5,6}$ In pregnancy, overt hypothyroidism is seen in $0.2 \%$ cases and subclinical hypothyroidism in $2.3 \%$ cases. Fetal loss, fetal growth restriction, preeclampsia and preterm delivery are the usual complications of overt hyperthyroidism seen in 2 of 1000 pregnancies whereas mild or subclinical hyperthyroidism is seen in $1.7 \%$ of pregnancies and not associated with adverse outcomes.

The prevalence of thyroid disorders during pregnancy has a wide geographical variation. Western literature shows a prevalence of hypothyroidism in pregnancy of $2.5 \%$ and hyperthyroidism in pregnancy has a prevalence of 0.1 to $0.4 \% .^{7}$ There is paucity of data on prevalence of thyroid disorders in Indian pregnant women; few reports show a prevalence of 4.8 to $11 \%$ amongst Indian pregnant population. ${ }^{8} 9$ So, this study was designed to determine the prevalence of thyroid dysfunction during early pregnancy and to evaluate the feto-maternal outcome in Eastern Uttar Pradesh. 


\section{METHODS}

This prospective observational study was carried out in the Department of Obstetrics and Gynecology, BRD Medical College, Gorakhpur over a period from August 2016 to July 2017. All antenatal women >18 years of age attending Department of Obstetrics and Gynecology for antenatal care with gestational age $\leq 20$ weeks, singleton pregnancy, irrespective of their gravida status (primigravida or multigravida) were included in the study. Women with multifetal gestation, pre-existing thyroid dysfunction, renal, hepatic or any other chronic illness, previous bad obstetric history with known cause were excluded from the study. Detailed history was taken focusing on symptoms of thyroid disorders, menstrual history and obstetric study. Thorough physical examination was done giving emphasis on clinical examination of thyroid and obstetrical examination. Blood grouping and $\mathrm{Rh}$ typing, complete blood examination, liver function test, renal function test, fasting glucose levels, serum electrolytes, complete urine examination, HIV, HBsAg, ultrasound scan of abdomen, FT3, FT4 and serum TSH levels were assessed in all the selected patients.

The reference ranges of the test values used in this study were as per the Guidelines of American Thyroid Association for the diagnosis and management of thyroid disease during pregnancy and postpartum. As per regulation of 14.2 of ATA Guidelines, if trimester specific ranges for $\mathrm{TSH}$ are not available in the laboratory, the following normal reference ranges are recommended: $1^{\text {st }}$ trimester- 0.1 to $2.5 \mathrm{~m} \mathrm{IU} / \mathrm{ml}, 2^{\text {nd }}$ trimester- 0.2 to $3.0 \mathrm{~m} \mathrm{IU} / \mathrm{ml}$ and $3^{\text {rd }}$ trimester- 0.3 to 3.0 $\mathrm{m} \mathrm{IU} / \mathrm{ml}$. Normal free T4 level is 0.7 to $0.8 \mathrm{n} / \mathrm{ml}$ and free T3 level is 1.7 to $4.2 \mathrm{pg} / \mathrm{ml}$. Depending on hormone values patients were classified into:

- Subclinical hypothyroidism-High serum TSH level with normal fT4 and fT3 level.

- Overt hypothyroidism-High serum TSH level with fT4 and fT3 less than normal range.

- Subclinical hyperthyroidism-Low serum TSH level with normal fT4 and fT3 level.

- Overt hyperthyroidism-Low serum TSH level with fT4 and fT3 more than normal range.

Subclinical/ overt hypothyroid cases were treated with Thyroxine. Subclinical/ overt hyperthyroid cases were treated with Propylthiouracil. Every 4 weeks, TSH level was estimated and the dose of the drug was adjusted. Patients were followed up until delivery and the pregnancy and fetal outcome were documented. An informed consent was obtained from every participant and the study was ethically approved by Institutional Ethical Committee.

\section{RESULTS}

In the current study, 152 out of 720 pregnant women screened had thyroid disorders. The prevalence of thyroid disorders in the present study was $21.11 \%$. The prevalence of subclinical hypothyroidism, overt hypothyroidism, subclinical hyperthyroidism and overt hypothyroidism was $15.9 \%, 2.7 \%, 1.6 \%$ and $0.5 \%$ respectively (Table 1$)$.

Table 1: The categories of thyroid dysfunction during pregnancy.

\begin{tabular}{|lllll|}
\hline Categories & No. of cases & $\%$ & TSH levels mean \pm SD & BMI mean \pm SD \\
\hline Subclinical hypothyroidism & 115 & 15.9 & $4.53 \pm 1.42$ & $23.46 \pm 1.6$ \\
\hline Overt hypothyroidism & 20 & 2.7 & $8.96 \pm 3.46$ & $24.67 \pm 1.4$ \\
\hline Subclinical hyperthyroidism & 12 & 1.6 & $0.024 \pm 0.016$ & $22.76 \pm 1.0$ \\
\hline Overt hyperthyroidism & 5 & 0.5 & $0.012 \pm 0.008$ & $21.82 \pm 1.2$ \\
\hline
\end{tabular}

Thus, hypothyroidism was found to be more common than hyperthyroidism. Amongst the patient with thyroid dysfunction, subclinical hypothyroidism was the most common thyroid disorder. In the present study, the mean BMI was $23.46 \pm 1.6 \mathrm{Kg} / \mathrm{m}^{2}$ for subclinical hypothyroid, $24.67 \pm 1.4 \mathrm{Kg} / \mathrm{m}^{2}$ for overt thyroid, $22.76 \pm 1.0 \mathrm{Kg} / \mathrm{m}^{2}$ for subclinical and $21.82 \pm 1.2 \mathrm{Kg} / \mathrm{m}^{2}$ for overt hyperthyroid patients. The obese women had higher TSH concentration and were prone to develop hypothyroidism than normal weight women. The mean TSH level in cases of subclinical hypothyroidism, overt hypothyroidism, subclinical hyperthyroidism and overt hyperthyroidism was $4.53 \pm 1.42 \mathrm{~m}$ IU/ $\mathrm{ml}, 8.96 \pm 3.46 \mathrm{~m}$ IU $/ \mathrm{ml}$, $0.02 \pm 0.016 \mathrm{~m} \mathrm{IU} / \mathrm{ml}$ and $0.012 \pm 0.008 \mathrm{~m} \mathrm{IU} / \mathrm{ml}$ respectively. The mean age of antenatal women was $24.8 \pm 4.09$ years and majority of them were multigravida (Table 2). $60.83 \%$ of women were illiterate, $29.44 \%$ had primary education and $9.72 \%$ had secondary education. Most of them were Hindus $(80.27 \%$ ) while $19.7 \%$ belonged to Muslim religion. 84.02\% women were from rural area and $15.97 \%$ were from urban area. Mean gestational age was found to be $11.2 \pm 3.92$ weeks. In the current study most, common complication observed in subclinical hypothyroidism was preeclampsia (9.56\%) followed by preterm delivery (7.82\%) and abortions. However, in overt hypothyroidism the incidence of preeclampsia, preterm delivery and abortions was $20 \%$, $10 \%$ and $5 \%$ respectively. 
Major fetal complications in hypothyroid mothers (subclinical as well as overt) were intrauterine growth restriction (IUGR), low birth weight and stillbirth.

Table 2: Sociodemographic profile of pregnant women.

\begin{tabular}{|c|c|c|}
\hline Variables & No. of cases & $\%$ \\
\hline \multicolumn{3}{|l|}{ Age (years) } \\
\hline$\leq 25$ & 446 & 61.94 \\
\hline $26-30$ & 202 & 28.05 \\
\hline $31-35$ & 72 & 10 \\
\hline \multicolumn{3}{|c|}{ Educational status } \\
\hline Illiterate & 438 & 60.83 \\
\hline Primary & 212 & 29.44 \\
\hline Secondary & 70 & 9.72 \\
\hline \multicolumn{3}{|l|}{ Food habits } \\
\hline Vegetarian & 446 & 61.94 \\
\hline Non-vegetarian & 274 & 30.05 \\
\hline \multicolumn{3}{|l|}{ Gravidity } \\
\hline Primigravida & 286 & 39.7 \\
\hline Multigravida & 434 & 60.27 \\
\hline \multicolumn{3}{|l|}{ Gestational age } \\
\hline$<12$ weeks & 440 & 61.11 \\
\hline$>12$ weeks & 280 & 38.89 \\
\hline \multicolumn{3}{|l|}{ Religion } \\
\hline Hindu & 578 & 80.27 \\
\hline Muslim & 142 & 19.7 \\
\hline \multicolumn{3}{|c|}{ Geographical distribution } \\
\hline Rural & 605 & 84.02 \\
\hline Urban & 115 & 15.97 \\
\hline
\end{tabular}

Out of 12 cases of subclinical hyperthyroidism, two patients developed preeclampsia, one had preterm delivery and one case had abortion.

Table 3: Maternal and fetal complications in hypothyroidism.

\begin{tabular}{|c|c|c|}
\hline Complications & No. of cases & $\%$ \\
\hline \multicolumn{3}{|c|}{ Maternal complications of subclinical hypothyroidism } \\
\hline Preeclampsia & 11 & 9.56 \\
\hline Preterm delivery & 9 & 7.82 \\
\hline Abortions & 5 & 4.3 \\
\hline Abruptio placenta & 2 & 1.7 \\
\hline \multicolumn{3}{|c|}{ Fetal complications of subclinical hypothyroidism } \\
\hline IUGR & 8 & 6.9 \\
\hline Low birth weight & 4 & 3.48 \\
\hline Still birth & 2 & 1.7 \\
\hline \multicolumn{3}{|c|}{ Maternal complications of overt hypothyroidism } \\
\hline Preeclampsia & 3 & 20 \\
\hline Preterm delivery & 2 & 10 \\
\hline Abortions & 1 & 5 \\
\hline Abruptio placenta & 1 & 5 \\
\hline \multicolumn{3}{|c|}{ Fetal complications of overt hypothyroidism } \\
\hline IUGR & 2 & 10 \\
\hline Low birth weight & 2 & 10 \\
\hline Still birth & 1 & 5 \\
\hline
\end{tabular}

Major fetal complications in subclinical hyperthyroid patients were IUGR (16.6\%), and stillbirth (8.33\%).

Table 4: Fetomaternal outcome in hyperthyroid patients.

\begin{tabular}{|c|c|c|}
\hline Outcome & No. of cases & $\%$ \\
\hline \multicolumn{3}{|c|}{ Maternal complications of subclinical hyperthyroidism } \\
\hline Pre-eclampsia & 2 & 16.6 \\
\hline Preterm delivery & 1 & 8.33 \\
\hline Abortions & 1 & 8.33 \\
\hline \multicolumn{3}{|c|}{ Fetal complications of subclinical hyperthyroidism } \\
\hline IUGR & 2 & 16.6 \\
\hline Stillbirth & 1 & 8.33 \\
\hline \multicolumn{3}{|c|}{ Maternal complications of overt hyperthyroidism } \\
\hline Abortion & 3 & 60 \\
\hline
\end{tabular}

\section{DISCUSSION}

Thyroid disorders are one of the most common endocrine disorders in women during pregnancy and are associated with adverse maternal and fetal outcomes in pregnancy. However, an early detection of thyroid dysfunctions and treatment of mother during gestation improves the outcome. ${ }^{10}$ Prevalence of thyroid dysfunction during pregnancy varies from 2.6- $10 \% .^{1,4,11-14}$ However, some studies done in India, Dhanwal et al and Ajmani et al have reported higher prevalence of thyroid dysfunction in pregnancy (14.5\% and $12 \%$ respectively). ${ }^{15,16}$ The higher prevalence of iodine deficiency could have been the reason for these figures among pregnant mothers in India. However, the current study demonstrated even higher prevalence of thyroid dysfunction (21.11\%) among pregnant mothers. This is comparable to the study performed by Bajaj et al and Rajput et al who found a prevalence of $24.07 \%$ and $26.5 \%$ respectively. ${ }^{17,18}$

In the present study, the prevalence of subclinical hypothyroidism is $15.9 \%$ and overt hypothyroidism is $2.7 \%$. This is in accordance to the study performed by Bajaj $\mathrm{S}$ et al who showed a prevalence of subclinical hypothyroidism $18.9 \%$ and overt hypothyroidism $2.46 \% .{ }^{17}$ Sahu et al have done thyroid function test in second trimester and reported prevalence of thyroid disorders, especially overt and subclinical hypothyroidism to be $6.47 \% .{ }^{19}$ Various reasons have been proposed for increased prevalence of hypothyroidism in pregnancy in Asia. Increased iodine intake in diet, presence of goitrogens in diet as reported from studies in India, deficiency of micronutrients like Selenium and iron are some of the reasons ascribed to the high hypothyroidism prevalence in India. ${ }^{20-22}$

In the current study, the prevalence of subclinical hypothyroidism was $1.6 \%$ which was comparable to the study performed by Thanuja et al $(1.3 \%) .{ }^{23}$ Prevalence of overt hyperthyroidism was found to be $0.5 \%$ which was in accordance to the study conducted by Taghvi et al $(0.6 \%)$ and Ajmani et al $(0.5 \%){ }^{16,24}$ The mean age at presentation is lower $(24.8 \pm 4.09$ years) compared to the 
western studies, namely, 27 \pm 6 years $25,29 \pm 5$ years 26 reflecting early marriage and early conception prevalent in India. The mean gestational age at presentation was 11.2 \pm 3.92 weeks indicating that most of the pregnant women in India do not visit the antenatal clinic during the first eight weeks of gestation.

Thyroid dysfunction has deleterious effect to both mother and fetus. In the current study, subclinical hypothyroidism is associated with complications like preeclampsia $(9.56 \%)$, preterm delivery $(7.82 \%)$, abortion $(4.3 \%)$, IUGR (6.9 \%), low birth weight $(3.48$ $\%)$ and still birth $(1.7 \%)$. This was in corroboration with the study performed by Sahu et al who showed that the women having subclinical hypothyroidism has complications like PE (9.8\%), preterm delivery $10.3 \%$, IUGR $2.4 \%$ and stillbirth $2.5 \%$.

However, in the study conducted by Taghvi et al the complications in pregnant women with subclinical hypothyroidism was preeclampsia $2.7 \%$ and preterm delivery $2.7 \%$ which was less than when compared to present study. ${ }^{26}$

In the present study, overt hypothyroidism in pregnancy was associated with complications like preeclampsia 20 $\%$, preterm delivery $10 \%$, IUGR $10 \%$, Low birth weight $10 \%$, abortions $5 \%$ and stillbirth $5 \%$. The results were comparable to the study performed by Sahu et al and Leung et al. ${ }^{27}$

Although hyperthyroid in pregnancy is uncommon, effects on both the mother and child are critical. In this study we observed that subclinical hyperthyroidism in pregnancy was associated with complications like preeclampsia $16.6 \%$, preterm delivery $8.33 \%$, abortions $8.33 \%$, IUGR $16.6 \%$ and stillbirth $8.33 \%$. Taghvi et al showed that $4.7 \%$ patients of subclinical hyperthyroidism developed hypertensive diseases of pregnancy. ${ }^{26,28}$

In a study by Robert Negro et al hyperthyroidism in pregnant women in low risk group was associated with gestational hypertension $16.7 \%$, preterm delivery $16.7 \%$ and abortion $14.3 \%$. Overt hyperthyroidism was associated with preeclampsia in $20 \%$ of patients. This was in consensus to the study performed by Kriplani et al. $^{29}$

There were two drawbacks in the present study first that TPO antibody levels were not examined in the patients and second that neonatal cord blood TSH levels were not examined in patients.

\section{CONCLUSION}

This study concludes that there is a high prevalence of hypothyroidism $21.11 \%$, majority being subclinical in pregnancy. Universal screening for thyroid function and timely and appropriate treatment will improve pregnancy outcome.

\section{ACKNOWLEDGMENTS}

Authors would like to thank Dr. Shaila Mitra, Head of Department of Pathology, BRD Medical College, Gorakhpur for the support during study.

\section{Funding: No funding sources}

Conflict of interest: None declared

Ethical approval: The study was approved by the Institutional Ethics Committee

\section{REFERENCES}

1. Allan WC, Haddow JE, Palomaki GE, Williams JR, Mitchell ML, Hermos RJ. et al, Maternal thyroid deficiency and pregnancy complications: implications for population screening. J Med Screen. 2000;7(3):127-30.

2. Casey BM, Leveno KJ. Thyroid disease in pregnancy. Obstetrics and Gynecology 2006;108(5): 1283-92.

3. Casey BM, Dashe JS, Wells CE, Mc Intire DD, Byrd EW, Lenovo KJ et al. Subclinical hypothyroidism and pregnancy outcomes. Obstet Gynecol 2005;105(2):239-45.

4. Abalovich M, Gutierrez S, Alcaraz G, Maccallini G, Garcia A, Levalle O. Overt and subclinical hypothyroidism complicating pregnancy. Thyroid. 2002;12(1):63-8.

5. Haddow JE, Palomaki GE, Allan WC, Williams JR, Knight GJ, Gagnon J, et al. Maternal thyroid deficiency during pregnancy and subsequent neuropsychological development of the child. New Eng J Med. 1999 341(8);549-55.

6. Pop VJ, Brouwers EP, Vader HL, Vulsma T, Van Baar AL, De Vijlder JJ. Maternal hypothyroxinaemia during early pregnancy and subsequent child development: a 3-year follow-up study. Clinic Endocrinol. 2003;59(3):282-8.

7. LeBeau SO, Mandel SJ. Thyroid disorders during pregnancy. Endocrinology Metabolism Clinics of North Am. 2006;35(1):117-36.

8. Nambiar V, Jagtap VS, Sarathi V, Lila AR, Kamalanathan S, Bandgar TR, et al. Prevalence and impact of thyroid disorders on maternal outcome in Asian-Indian pregnant women. J Thyroid Res. 2011;2011:4290-7.

9. Sahu MT, Das V, Mittal S, Agarwal A, Sahu M. Overt and subclinical thyroid dysfunction among Indian pregnant women and its effect on maternal and fetal outcome. Arch Gynecol Obstetrics. 2010;281(2):215-20.

10. Lazarus JH. Thyroid functions in pregnancy. Br Med Bull. 2011;97(1):137-48.

11. Altomare M, La Vignera S, Asero P, Recupero D, Condorelli RA, Scollo P, et al. High prevalence of thyroid dysfunction in pregnant women. J Endocrinol Investigat. 2013;36(6):407-11.

12. Glinoer D, Riahi M, Grun JP, Kinthaert J. Risk of subclinical hypothyroidism in pregnant women with 
asymptomatic autoimmune thyroid disorders. J Clinic Endocrinol Metabol.1994;79(1):197-204.

13. Moreno-Reyes R, Glinoer D, Van Oyen H, Vandevijvere S. High prevalence of thyroid disorders in pregnant women in a mildly iodine deficient country: a population-based study. Journal of Clinic Endocrinol Metabol.2013;98(9):3694-701.

14. Pratt DE, Kaberlein G, Dudkiewicz A, Karande V, Gleicher N. The association of antithyroid antibodies in euthyroid nonpregnant women with recurrent first trimester abortions in the next pregnancy. Fertil Steril. 2000;60(6):1001-5.

15. Dhanwal DK, Prasad S, Agarwal AK, Dixit V, Banerjee A K. High prevalence of subclinical hypothyroidism. Indian $\mathrm{J}$ Endocrinol Metabol. 2013;17(2):281-4.

16. Ajmani SN, Aggarwal D, Bhatia P, Sharma M, Sarbhai V, Paul M. Prevalence of Overt and Subclinical Thyroid Dysfunction Among Pregnant Women and Its Effect on Maternal and Fetal Outcome. J Obstet Gynecol India. 2014;64(2):10510.

17. Bajaj S, Chawla T, Gupta P, Chaurasia A, Mehrotra R. Thyroid dysfunction in pregnancy- A tertiary care centre experience. Sri Lanka J Diab, Endocrinol Metabol. 2016;6(1):3-6.

18. Rajput R, Goel V, Nanda S, Rajput M, Seth S. Prevalence of thyroid dysfunction among women during the first trimester of pregnancy at a tertiary care hospital in Haryana. Ind $\mathbf{J}$ Endocrinol Metab, 2015;19(3):416-9.

19. Sahu MT, Das V, Mittal S, Agarwal A, Sahu M. Overt and subclinical thyroid dysfunction among Indian pregnant women and its effect on maternal and fetal outcome. Arch Gynecol Obstetrics. 2010;281(2):215-20.

20. Teng X, Shan Z, Chen Y, Lai Y, Yu J, Shan L, et al. More than adequate iodine intake may increase subclinical hypothyroidism and autoimmune thyroiditis: A cross-sectional study based on two Chinese communities with different iodine intake levels. Eur J Endocrinol. 2011;164(6):943-50.

21. Marwaha RK, Tandon N, Gupta N, Karak AK, Verma K, Kochupillai N. Residual goitre in the postiodization phase: Iodine status, thiocyanate exposure and autoimmunity. Clin Endocrinol (Oxf). 2003;59(6):672-81.

22. Das S, Bhansali A, Dutta P, Aggarwal A, Bansal MP, Garg D, et al. Persistence of goiter in the postiodization phase: micronutrient deficiency or thyroid autoimmunity? Indian J Med Res. 2011;133(1):103-9.

23. Thanuja PM, Rajgopal K, Sadiqunnisa. Thyroid dysfunction in pregnancy and its maternal outcome. $\mathrm{J}$ Dent Med Sci:2014;13(1):11-5.

24. Taghavi M, Saghafi N, Shirin S. Outcome of Thyroid Dysfunction in Pregnancy in Mashhad, Iran. Int $\mathbf{J}$ Endocrinol Metab, 2009;2(3):82-5.

25. B. Vaidya, S. Anthony, M. Bilous et al., "Detection of thyroid dysfunction in early pregnancy: universal screening or targeted high-risk case finding?" The J Clinic Endocrinol Metabol. 2007;92(1):203-7.

26. Abalovich M, Gutierrez S, Alcaraz G, Maccallini G, Garcia A, Levalle O. Overt and subclinical hypothyroidism complicating pregnancy. Thyroid. 2002;12(1):63-8.

27. Leung AS, Millar LK, Koonings PP, Montoro M, Mestman JH. Perinatal outcome in hypothyroid pregnancies. Obstet Gynecol. 1993;81(3):349-353.

28. Negro R, Schwartz A, Gismondi R, Tinelli A, Mangieri $\mathrm{T}$ and Stagnaro-Green A. Universal screening versus case finding for detection and treatment of thyroid hormonal dysfunction during pregnancy. J Clinic Endocrinol Metabol. 2010;95(4):1699-707.

29. Kriplani A, Buckshee K, Bhargava VL, Takkar D, Ammini AC. Maternal and perinatal outcome in thyrotoxicosis complicating pregnancy. Eur J Obstet Gynecol Reprod Biol, 1994;54(3):159-63.

Cite this article as: Kumari A, Srivastav R, Mitra S. Prevalence of thyroid dysfunction and its effects on fetomaternal outcome in pregnant women of Eastern Uttar Pradesh, India. Int J Reprod Contracept Obstet Gynecol 2018;7:4379-83. 